\title{
Azot-Katkılı 3 Boyutlu Grafen Mimari Üzerinde Desteklenen Paladyum Nanopartiküllerin Doğrudan Metanol Yakıt Hücrelerinde Elektrokatalizör Olarak Kullanılabilirliğinin İncelenmesi
}

\author{
Onur KARAMAN* \\ Akdeniz Üniversitesi, Să̆llk Hizmetleri Meslek Yüksekokulu, Tıbbi Görüntüleme Teknikleri Programı, Antalya \\ (ORCID: 0000-0003-3672-1865)
}

\begin{abstract}
$\ddot{O} \mathbf{z}$
Yüksek elektroaktif özelliğe sahip elektrokatalizörlerin tasarımı, yüksek güç yoğunluğuna sahip taşınabilir yakıt hücresi sistemlerinin geliştirilmesinde kritik bir nokta olarak kabul edilmektedir. Bu çalışmada, doğrudan metanol yakıt hücresinde elektrokatalizör olarak kullanılabilecek azot-katkılı 3-boyutlu grafen (N-3DG) mimarisi ile desteklenen Paladyum (Pd) nanoparçacıklarının sentezi için kolay ve düşük maliyetli bir üretim yöntemi önerilmiştir. Güçlü sinerjik etkilerin yanı sıra benzersiz yapısal özelliklere sahip olan Pd/N-3DG hibrit elektrokatalizörü, metanol elektrooksidasyonuna karşı, ticari Pd elektrokatalizöründen (Pd/Vulcan XC-72R) daha yüksek anodik tepe akım yoğunluk değerleri ve daha yüksek katalitik kararlılık gibi üstün elektrokatalitik performans sergilemiştir. Bu çalışma, yakıt pili teknolojisinde ticari Pd elektrokatalizörlerine alternatif olarak kullanılabilecek yüksek performanslı, düşük maliyetli elektrokatalizörlerin üretilmesi için yeni bir yaklaşımın yolunu açmaktadır.
\end{abstract}

Anahtar kelimeler: Azot Katkılı Grafen, 3 Boyutlu Grafen, Elektrokatalizör, Doğrudan Metanol Yakıt Hücresi, Metanol Oksidasyonu, Paladyum Nanoparçacıkları.

\section{Investigation of The Potential Usage of Palladium Nanoparticles Supported on Nitrogen Doped 3 Dimensional Graphene Architecture As Electrocatalysts in Direct Methanol Fuel Cells}

\begin{abstract}
The engineering of highly electroactive electrocatalysts is considered a critical point in the development of high power density portable fuel cell systems. In this study, a facile and low-cost fabrication method for the synthesis of Pd nanoparticles supported by nitrogen-doped 3-dimensional graphene (N-3DG) architecture, which can be used as an electrocatalyst directly in methanol fuel cell, is proposed. Pd/N-3DG hybrid electrocatalyst, which has unique structural properties as well as strong synergistic effects, exhibited superior electrocatalytic performance towards methanol electrooxidation, such as higher anodic peak current density values and higher catalytic stability than the commercial Pd electrocatalyst (Pd/Vulcan XC-72R). This study paves the way for a novel approach for fabricating high-performance, low-cost electrocatalysts that may be utilized as an alternative to commercial Pd electrocatalysts in fuel cell technology.
\end{abstract}

Keywords: Nitrogen Doped Graphene, 3 Dimensional Graphene, Electrocatalyst, Direct Methanol Fuel Cell, Methanol Oxidation, Palladium Nanoparticles

\section{Giriş}

Son yıllarda, gelişen endüstriyelleşme ve nüfus artışına bağlı olarak artan enerji ihtiyacı ve fosil yakıtların yanması sonucu oluşan çevre kirliliği gibi sorunlar yakıt hücresi sistemleri gibi alternatif enerji dönüşüm sistemlerine olan ilgiyi beraberinde getirmiştir [1-3]. Yakıt hücreleri, harici yakıt (anot

"Sorumlu yazar: onurkaraman@akdeniz.edu.tr

Geliş Tarihi: 10.06.2021, Kabul Tarihi: 12.08.2021 
tarafi) ve oksitleyici (katot tarafi) ile elektrik üreten elektrokimyasal reaksiyon yoluyla bir yakıtın enerjisini doğrudan elektrik enerjisine dönüştüren sistemlerdir [4]. Yakıt hücresinde gerçekleşen elektrokimyasal reaksiyonlar, katalizör-elektrolit ara yüzeyinde meydana gelir [5,6]. Çeşitli yakıt hücresi türleri arasında, doğrudan metanol yakıt hücresi (DMFC), kolay cihaz yapıları, daha yüksek enerji dönüşüm verimliliği, daha düşük çalışma sıcaklığı, daha az tehlikeli gaz emisyonu ve sıvı yakıtların daha uygun depolanması ve taşınması gibi avantajlar nedeniyle son derece umut verici enerji dönüşüm sistemleri olarak kabul edilmektedir [7].

Doğrudan metanol ve formik asit yakıt hücreleri gibi bir sıvı yakıt kaynağı kullanan sıv1beslemeli yakıt pilleri, anotta yakıt oksidasyonu reaksiyonu ve katotta oksijen indirgeme reaksiyonu için elektrokatalizör gerektiren elektrokimyasal hücrelerdir [8]. Yüksek enerji yoğunluğu başta olmak üzere çeşitli faydalar sunmalarına rağmen, sıvı beslemeli yakıt hücreleri, hidrojen oksidasyon reaksiyonuna kıyasla yavaş anot yakıt oksidasyon kinetiği nedeniyle hala dezavantaja sahiptir [9]. Yakıt hücresinin sunacağı enerji yoğunluğu doğrudan kullanılan elektrot katalizörünün elektrokimyasal aktivitesi ile ilişkilidir. Platin, Paladyum, Rutenyum, Rodyum gibi soy metaller ve soy metal-temelli alaşımların, benzersiz katalitik özelliklerinden dolayı yakıt hücreleri için en yaygın kullanılan anot elektrokatalizörleri olduğu bilinmektedir [10]. Bununla birlikte, soy metal-temelli elektrokatalizörlerin sınırlı kaynakları, yüksek maliyetleri ve düşük $C O$ veya metanol zehirlenme toleransları, yakıt hücrelerinin büyük ölçekli ticari uygulamalarını büyük ölçüde engellemektedir. Bu nedenle, ticari soy metal elektrokatalizörlerle kıyaslanabilir performansa ve daha yüksek CO ve metanol toleransına sahip düşük maliyetli alternatif elektrokatalizörlerin araştırılması büyük önem taşımaktadır. Son yıllarda yürütülen teorik ve deneysel araştırmalar, daha düşük maliyetli Pd-temelli anot katalizörlerinin, Pttemelli eletrokatalizörlerinkinden daha yüksek elektrokatalitik aktiviteye ve daha üstün CO toleransına sahip olabileceğini göstermiştir. Bahsedilen sorunları önlemek için önerilebilecek stratejilerden biri de Pd nanoparçacıklarını geniş spesifik yüzey alanı ve iyi elektrik iletkenliğe sahip uygun destek katalizör üzerine dekore etmektir. Bu amaçla, Pd nanokristallerinin boyutlarını ve morfolojisin kontrol etmek, kararlılığını artırabilmek için karbon nanotüpler, karbon nanofiberler, karbon siyahı ve grafen de dâhil olmak üzere çeşitli karbon temelli malzemeler destek katalizör olarak kullanılabilmektedir [11-14]. Bu karbon malzemeler arasında, sp2 hibrit karbon atomlarından oluşan iki boyutlu bir nanomalzeme olan grafen, son derece yüksek spesifik yüzey alanı, mükemmel elektriksel iletkenliği ve üstün kimyasal kararlılı̆̆ 1 nedeniyle en umut verici destek katalizörlerden biri olarak düşünülmektedir [6]. Ancak, grafen katmanlarının yeniden istiflenmesi ve aglomerasyon sorunu, yüksek elektrokatalitik aktiviteye sahip iki boyutlu (2B) grafen yapılarının sentezinin önündeki ana engeldir. Öte yandan, üç boyutlu (3D) grafen mimariler, birbirine bağlı hiyerarşik sıralı gözenek yapısı, bol aktif bölgelere sahip geniş spesifik yüzey alanı, üstün elektrik iletkenliği ve elektrokimyasal erişilebilir yüzey alanı, hafifliği ve üstün mekanik özellikleri sayesinde birçok üstünlüğe sahiptir [2]. Bununla birlikte, grafen yapılara heteroatomların (azot, kükürt, bor, vb.) katkısı ile elektronik yapı ve elektrokimyasal aktivitesinin iyileştirilmesinin yanı sıra özellikle soy metal nanoparçacıklarının boyutlarını kontrol etmesi, metal ve karbon destekler arasındaki etkileşimi güçlendirmesi beklenmektedir $[2,15,16]$. Yapılan çalışmalar, grafen mimariye heteroatom katkılanması ile çok daha fazla elektroaktif bölge sağlanabileceğini ve bu sayede daha üstün elektrokatalitik performans sunabileceğini göstermiştir [2]. Bu kapsamda, düşük maliyetli üstün performanslı gelişmiş yakıt hücresi sistemlerinin tasarlanabilmesi için büyük bir potansiyel sunacak olan Pd nanoparçacık ve heteroatom katkılı 3D grafen mimariden oluşan yüksek performanslı hibrit elektrot katalizörlerinin üretimi büyük önem taşımaktadır. Bilindiği kadarıyla, şimdiye kadar $\mathrm{Pd} / \mathrm{N}-k a t k ı 1 ı$ 3D grafen hibrit elektrokatalizörlerinin üretimi ve doğrudan metanol yakıt hücresi anot elektrokatalizörü olarak kullanılabilirliği üzerine az sayıda çalışma rapor edilmiştir. Tüm bunlar göz önünde bulundurularak, bu çalışmada, Pd nanoparçacık dekore edilmiş N-katkılı 3D grafen elektrokatalizörler hidrotermal/solvotermal üretim yöntemi ile üretilmiş, fizikokimyasal karakaterizasyonu gerçekleştirilmiş ve elektrokatalitik metanol oksidasyonu araştırılmıştır.

\section{Materyal ve Metot}

\subsection{N-Katkılı Grafen Nanotabakalarının Sentezlenmesi}

İlk olarak, grafen oksit (GO), daha önceki çalışmada tarif edildiği gibi modifiye Hummers yöntemiyle ticari grafit tozundan hazırlanmıştır [2]. Ardından, N atomunun, grafen yapı üzerine katkılanması için, 
$50 \mathrm{~mL} \mathrm{GO}\left(0.5 \mathrm{mg} \cdot \mathrm{mL}^{-1}\right)$ sulu dispersiyonuna $50 \mathrm{mg}$ üre eklenerek, 2 saat boyunca ultrasonik banyoda dispersiye edilmiş̧ir. Elde edilen GO-üre dispersiyonu, Teflon kaplı paslanmaz çekik otoklav reaktöre aktarıldı ve $160{ }^{\circ} \mathrm{C}^{\prime}$ de 8 saat reaksiyon gerçekleştirilmiştir. Hidrotermal reaksiyon ile yapıdaki $\mathrm{N}$ atomlarının, GO yüzeyindeki fonksiyonel gruplarla etkileşime girmesi ve grafen katmanlarındaki karbon kafeslerine katkılanması sağlanmıştır. Aynı zamanda, GO’nun hidrotermal kendiliğinden birleşme yoluyla, grafene indirgenerek istenen N-katkılanmış 3D grafen nano tabakaları (N-3DG) elde edilmiştir.

\subsection{Pd/N-3DG Hibrit Elektrokatalizörlerinin Üretilmesi}

Hidrotermal yöntemle üretilen N-3DG (20 mg), homojen bir dispersiyon oluşturmak üzere $40 \mathrm{ml}$ etilen glikol ve $40 \mathrm{ml}$ deiyonize su içinde ultrasonik olarak dağıtılmıştır. Ardından, $\mathrm{K}_{2} \mathrm{PdCl}_{4}$ çözeltisi $(0.1 \mathrm{M}$, $0.50 \mathrm{~mL}$ ), N-3DG dispersiyonuna eklendikten sonra elde edilen karışım $30 \mathrm{dk}$ manyetik karıştırıcıda karıştırılmıştır. Daha sonra, elde edilen reaksiyon karışımı, Teflon kaplı paslanmaz çelik otoklava aktarılarak, $120^{\circ} \mathrm{C}^{\prime}$ de 15 saat belketilmiştir. Elde edilen nihai ürün $(\mathrm{Pd} / \mathrm{N}-3 \mathrm{DG})$ santrifüjlenerek ayrılmıştır. Son olarak, Pd/N-3DG, etilen ve deiyonize su ile yıkandı ve daha sonra 24 saat boyunca dondurularak kurutulmuştur. Karşılaştırma için, ticari Vulcan XC-72R üzerinde desteklenen $\mathrm{Pd}$ nanoparçacıklar $(\mathrm{Pd} / \mathrm{C})$, aynı yöntemle hazırlanmıştır. Hazırlanan tüm katalizörlerin paladyum içeriği ağırlıkça $\sim 20$ 'dir.

\subsection{Elektrokatalizörlerin Yapısal Karakterizasyonu}

Hazırlanan elektrokatalizörlerin yüzey morfolojisi ve nanoyapıları, taramalı elektron mikroskobu (SEM, ZEISS EVO 50 SEM) ve yüksek çözünürlüklü transmisyon elektron mikroskobu (HRTEM, JEOL JEM2100) ile araştırılmıştır. Numunelerin X-1şını kırınım (XRD) desenleri, Rigaku (Ultima-IV) X-1şını kırınım ölçeri $(\lambda=0,154 \mathrm{~nm})$ ile elde edilmiştir. Numunelerin X-ışını fotoelektron spektrumları (XPS), Thermo ESCALAB 250 XPS cihazı ile kaydedilmiştir.

\subsection{Elektrokatalitik Performans Karakterizasyonu}

Üretilen Pd/N-3DG ve Pd/C elektrokatalizörlerinin elektrokatalitik performans1, Gamry Reference-600 elektrokimyasal iş istasyonunda test edilmiştir. Tipik bir üç elektrotlu elektrokimyasal hücrede, karş1 elektrot olarak Pt-tel ve referans elektrot olarak doygun klomel elektrot (SCE) kullanılarak metanol oksidasyon ölçümleri gerçekleştirilmiştir. Çalışma elektrotu olarak katalizör mürekkebi ile modifiye edilmiş camsı karbon elektrot (GCE) kullanılmıştır. GCE modifikasyonu için, 2 mg katalizör tozu, homojen bir dispersiyon oluşturmak üzere 30 dakika boyunca ultrasonikasyon ile $500 \mu \mathrm{L}$ su, $500 \mu \mathrm{L}$ etanol ve $50 \mu \mathrm{L} \% 5$ Nafion 117 çözeltisi içinde dağıtılarak katalizör mürekkebi elde edilmiştir. Daha sonra, elde edilen katalizör mürekkebinin $5 \mu$ L'si dikkatli bir şekilde GC elektrot yüzeyine kaplanmış ve kaplama oda sıcaklığında kurutulmuştur. Tüm elektrotlar üzerindeki Pd yükleme miktarı $\sim 0.028$ mg. $\mathrm{cm}^{-2}$ olarak standardize edilmiştir. Metanol oksidasyonu için döngüsel voltametri (CV) ölçümleri, $0.5 \mathrm{M} \mathrm{NaOH}+1.0 \mathrm{M}$ metanol elektrolitinde $50 \mathrm{mV} . \mathrm{s}^{-1}$ potansiyel tarama hızında gerçekleştirilmiştir. Elektrokatalizörlerin, dayanıklılık (3000 s) ölçümleri için metanol oksidasyonunun kronoamperometri (CA) ölçümleri aynı elektrolit çözeltisinde 0.2 V'ta elde edilmiştir.

\section{Bulgular ve Tartışma}

\subsection{Elektrokatalizörlerin yapısal karakterizasyonu}

$\mathrm{Pd} / \mathrm{C}$ ve Pd/N-3DG elektrokatalizörlerine ait FE-SEM görüntüleri sırasıyla Şekil 1A ve Şekil 1B'de sunulmuştur. Pd/C'ye ait SEM görüntüsü (Şekil 1A) amorf karbon yapısı sergilerken, hidrotermal olarak sentezlenmiş $\mathrm{Pd} / \mathrm{N}-3 \mathrm{DG}$, mikro ve makro gözenekli, birbirine bağlı 3D gözenekli bir mimari sergilemektedir. Elektrokatalizörlere ait TEM görüntüleri yarı-küresel yapıdaki Pd nanoparçacıklarının karbon destek üzerindeüzerinde rastgele homojen olarak dağılmış olduğunu kanıtlamaktadır (Şekil 1C ve Şekil 1D). Pd/C elektrokatalizörü için hesaplanan ortalama partikül boyutu ( $\left.\mathrm{d}_{\text {ort }}\right) 7.9 \mathrm{~nm}$ iken Pd/N3DG hibrit elektrokatalizörü için bu değer $6.8 \mathrm{~nm}$ olarak hesaplanmıştır. 

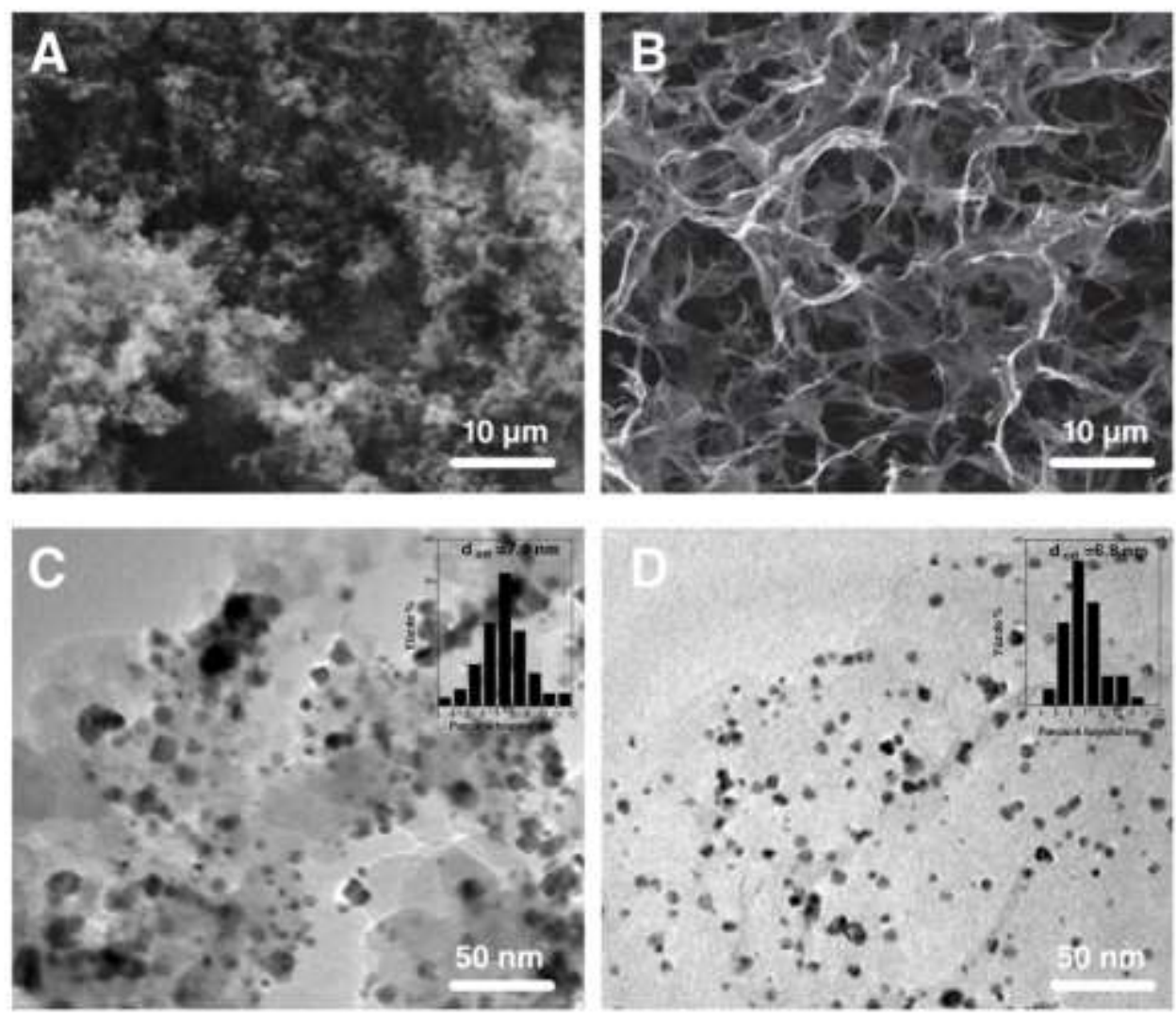

Şekil 1. Sırasıyla Pd/C ve Pd/N-3DG elektrokatalizörlerine ait (A)-(B) SEM görüntüleri, (C)-(D) TEM görüntüleri (C-D şekil içi Pd parçacık boyutu dağılımıları sunulmuştur)

Elektrokatalizörlerin ve GO'nun kristal yapısındaki hakkında bilgi X-1şını kırınım (XRD) analizi ile incelendi (Şekil 2A). Şekil 2A, Pd/N-3DG, Pd/C ve GO örneklerinin XRD spektrumlarını göstermektedir. GO'ya ait XRD spektrumunda görüldüğü gibi, yaklaşık $2 \theta=10.5^{\circ}$ de bulunan keskin kırınım tepe noktası (001) düzlemindeki yansıma ile ilişsilidir ve doğal grafit $(0.34 \mathrm{~nm})$ ile karşılaştırıldığında esas olarak oksijenli fonksiyonel grupların varlığı nedeniyle çok daha büyük tabaka aralığına $(\sim 0.87 \mathrm{~nm})$ sahip olduğu gözlenmiştir [2]. Pd/N-3DG ve Pd/C elektrokatalizörleri için, bu karakteristik zirve, sentez işlemi sırasında GO tabakalarında yer alan oksijenli fonksiyonel grupların uzaklaştı̆̆ının göstergesi olan geniş bir profil ile $2 \theta=25.0^{\circ}$ 'a kaymıştır. Ayrıca, $\mathrm{Pd} / \mathrm{N}-3 \mathrm{DG}$ ve $\mathrm{Pd} / \mathrm{C}^{\prime} \mathrm{de}$ yaklaşık $2 \theta=39.8^{\circ}, 2 \theta=46.2^{\circ}$ ve $2 \theta=67.7^{\circ}$ de gözlenen diğer üç kırınım zirvesi, kübik yapıdaki metalik Pd'nin sırasiyla (111) düzlemi, (200) düzlemi ve (220) düzlemine atfedilebilir (JCPDS no. 46-1043) [17].

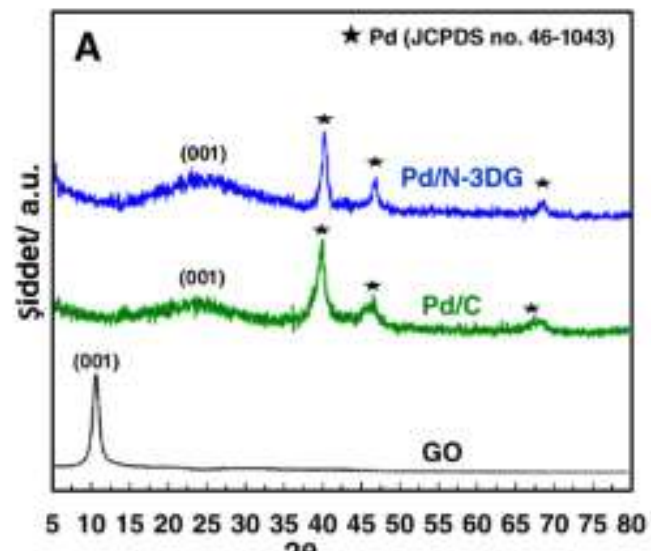

$2 \theta$

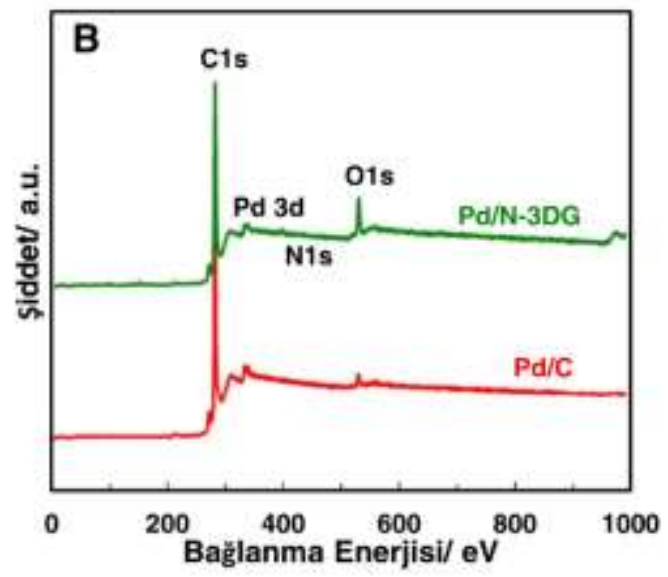

Şekil 2. $\mathrm{Pd} / \mathrm{C}$ ve $\mathrm{Pd} / \mathrm{N}-3 \mathrm{DG}$ elektrokatalizörlerine ait (A) XRD ve (B) tam tarama XPS spektrumları 
Elektrokatalizörlerin element bileşimi hakkında daha fazla bilgi edinmek için XPS ölçümleri gerçekleştirilmiştir (Şekil 2B). Sırasıyla C1s, Pd 3d, ve O1s sinyallerine ait karakteristik tepe noktaları yaklaşık 285.0, $340.0 \mathrm{eV}$ ve $530.0 \mathrm{eV}$ bağlanma enerjilerinde gözlenmiştir [6]. Pd/C elektrokatalizörüne ait XPS spektrumunda, N1s'e ait herhangi bir pik gözlenmemişken, Pd/N-3DG hibrit elektrokatalizörüne ait spektrumda yaklaş1k $400.0 \mathrm{eV}$ civarında görülen pik N1s'e ait olup, yapıya başarıyla azot katkılandığını doğrulamıştır. Pd/N-3DG hibrit elektrokatalizörüne ait $\mathrm{N}$ içeriği ağırılıkça $\% 2.21$ olarak belirlenmiştir.

\subsection{Elektrokatalizörlerin elektrokimyasal karakterizasyonu}

Üretilen elektrokatalizörlerin metanol elektrooksidasyonu için bir anot elektrokatalizörü olarak kullanılabilirliği yarı-hücre koşullarında, argon ile doyurulmuş $1.0 \mathrm{M}$ metanol $+0.5 \mathrm{M} \mathrm{NaOH}$ elektrolitinde, dönüşümlü voltametri tekniği ile test edilmiştir. Tüm elektrokatalizörler için elde edilen $\mathrm{CV}$ eğrileri, belirgin bir geniş anodik tepe noktası sergilerken ve nispeten zayıf bir katodik tepe noktası sunmuştur (Şekil 3A). Şiddetli anodik pik, kimyasal olarak absorbe edilmiş metanolün oksidasyonundan kaynaklanırken, katodik taramada tamamen oksitlenmeyen karbonlu ara ürünlerden kaynaklanmaktadır. İleri yöndeki taramadaki başlangıç potansiyeli $\left(E_{\text {onset }}\right)$ ve tepe akım yoğunluğu $\left(I_{f}\right)$, reaksiyon dinamik özelliğini ve katalizör aktivitesini tahmin etmek için kullanılmaktadır. Maksimum $I_{f}$ ve minimum $E_{\text {onset }}$, $\mathrm{Pd} / \mathrm{N}$-3DG hibrit elektrokatalizörünün, $\mathrm{Pd} / \mathrm{C}$ 'den daha yüksek elektrokatalitik aktiviteye ve metanol oksidasyonu için reaksiyon kinetiğinde önemli artışa sahip olduğunu gösterir. Pd nanoparçacıkları ve N-katkılamanın sinerjik etkisi ile Pd/N-3DG, yüksek elektrokatalitik aktivite $\left(11.8 \mathrm{~mA} . \mathrm{cm}^{-2}\right)$ sergilemiştir. Bu durum, Pd/N-3DG'nin yapısal tasarımının metanol oksidasyonunun elektrokatalizi için elverişli olduğunu doğrulamıştır. Elde edilen veriler Tablo 1'de sunulduğu gibi her elektrot üzerindeki Pd yüklemesine göre standardize edilmiştir. Pd/N-3DG elektrotunun kütle aktivitesi $400.3 \mathrm{~mA} \cdot \mathrm{mg}^{-1}$ olarak hesaplanmıştır. Pd/N-3DG hibrit elektrokatalizörü, $\mathrm{Pd} / \mathrm{C}$ elektrotundan daha iyi performans sergilemiştir.

Tablo 1. DMFC koşullarında Pd/C ve Pd/N-3DG elektrotlarının elektrokimyasal davranışı

illeri Yöndeki Tepe Akım Yoğunluğu

\begin{tabular}{|c|c|c|}
\hline Elektrot & $\begin{array}{l}\text { Spesifik Aktivite } \\
m A . \mathrm{cm}^{-2}\end{array}$ & $\begin{array}{l}\text { Gravimetrik Aktivite } \\
m A . m g^{-1}\end{array}$ \\
\hline$P d / C$ & 5.9 & 188.4 \\
\hline$P D / N-3 D G$ & 11.8 & 400.3 \\
\hline
\end{tabular}
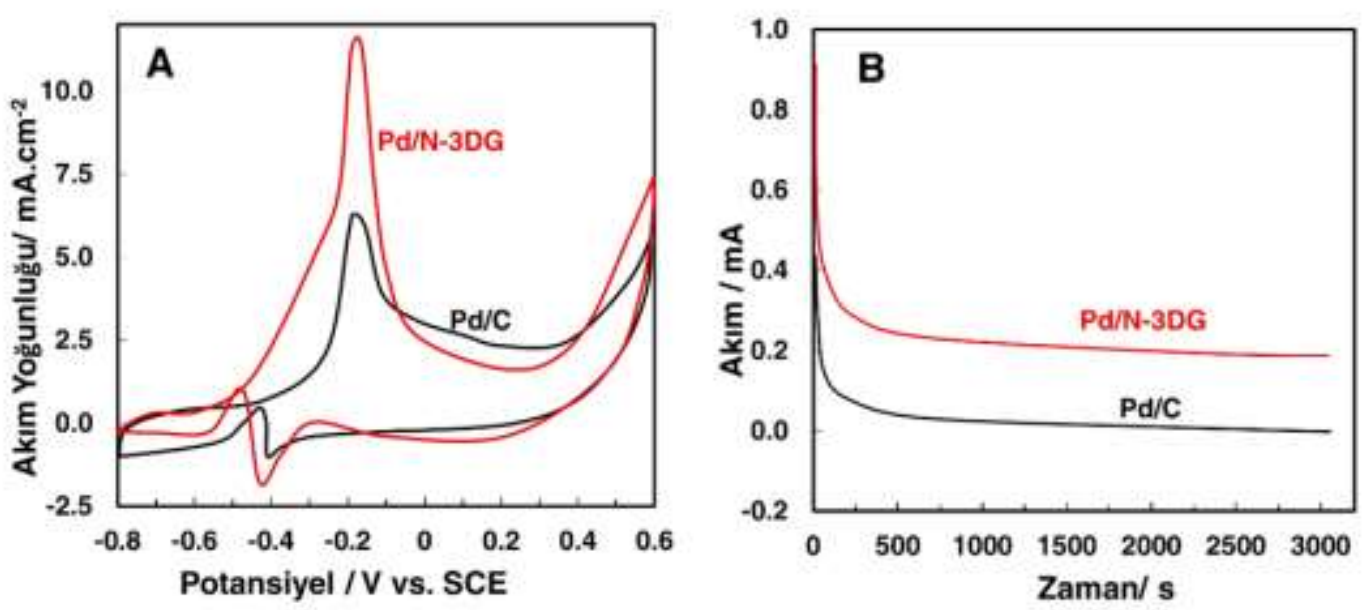

Şekil 3. $\mathrm{Pd} / \mathrm{N}-3 \mathrm{DG}$ ve $\mathrm{Pd} / \mathrm{C}$ elektrotlarının $0.5 \mathrm{M} \mathrm{NaOH}+1.0 \mathrm{M}$ metanol elekrolitinde (a) $50 \mathrm{mV} . \mathrm{s}^{-1}$ potansiyel tarama hızında CV voltammogramları (b) $0.20 \mathrm{~V}$ (vs SCE) elde edilen kaydedilen kronoamperometrik eğriler 
Elektrokatalizörlerin uzun vadeli elektrokatalitik kararlılığı, taşınabilir yakıt hücrelerinin pratik kullanımları için önemli bir göstergedir. Bu kapsamda, elektrokatalizörlerin kararlılığını araştırmak için kronoamperometri ölçümleri gerçekleştirilmiştir (Şekil 3B). Başlangıçta, toksik ürünlerin birikmesine bağlı olarak sınır akımı hızla düşmüştür. Şekil 3B'den görülebileceği gibi, Pd/N-3DG hibrit elektrokatalizörün kronoamperometri eğrisi, $\mathrm{Pd} / \mathrm{C}$ elektrokatalizörüne kıyasla daha az akım bozulmasına uğramıştır.

Elde edilen bulgular, Pd nanoparçacıklarının N-3DG destek katalizör üzerine kombinasyonunun, elektrokatalizörün elektrokatalitik performansının artırılabileceğini ortaya koymuştur. Pd/N-3DG hibrit elektrokatalizörünün üstün elektrokimyasal özellikleri (i) 3D grafen mimari üzerinde homojen olarak dağılmış olan küçük parçacık boyutlarına sahip Pd nanopartiküllerin katalitik aktiviteyi büyük ölçüde artıran çok sayıda aktif merkezler sunmasına; (ii) 3 boyutlu mimariye sahip grafen tabakalar, yalnızca reaktanların etkin bir kütle transferi için yüksek yüzey alanları sağlamakla kalmaz, aynı zamanda katalitik sistemdeki hızlı elektron difüzyonları için benzersiz "süper otoyollar" olarak da işlev görmesine; (iii) 3D grafen mimariye $\mathrm{N}$ atomu katkılanması, grafenin elektronik yapılarını önemli ölçüde değiştirmesine, böylece spin yoğunluğunu artırmasına ve destekleyici malzemenin katalitik kabiliyetini yükseltmek için komşu karbon atomlarını aktive edebilmesine; (iv) 3D grafen mimarisinde $\mathrm{N}$ atomlarının varlığı ayrıca $\mathrm{Pd}$ ve destek katalizör arasında güçlü bir etkileşim sağlaması ile açıklanabilir. Sonuç olarak, üretilen Pd/N-3DG hibrit elektrokatalizörü üstün elektrokatalitik özelliklerle donatılmıştır ve gelişmiş enerji dönüştürme cihazlarında büyük umut vaat eden bir uygulama sunar [18-19].

\section{Sonuç ve Öneriler}

$\mathrm{Bu}$ çalışmada, Pd nanoparçacıkların N katkılı 3D grafen mimari üzerinde biriktirilmesi için pratik bir üretim yöntemi sunulmuştur. Geniş yüzey alanı, N atomlarının varlığı, küçük Pd nanoparçacıklarının homojen dağılımı ve iyi elektriksel iletkenlik gibi yapısal avantajlar sayesinde elde edilen Pd/N-3DG, üstün elektrokatalitik aktivite, uzun süreli dayanıklılık ve metanol oksidasyonuna karşı geleneksel $\mathrm{Pd} / \mathrm{C}$ katalizörlerinden daha üstün performans göstermiştir. Üretilen hibrit yapının yakıt hücrelerinde kullanılabilir olmasının yanı sıra, bu tür nanomalzemelerin sensörler, fotokataliz ve enerji depolama sistemleri gibi diğer uygulamalar için de potansiyel adaylar olması çalışmayı önemli kılmaktadır.

\section{Yazarların Katkısı}

Makalede tüm katkı şahsıma aittir.

\section{Çıkar Çatışması Beyanı}

Yazarlar arasında herhangi bir çıkar çatışması bulunmamaktadır.

\section{Araştırma ve Yayın Etiği Beyanı}

Yapılan çalışmada araştırma ve yayın etiğine uyulmuştur.

\section{Kaynaklar}

[1] Arico A.S., Bruce P., Scrosati B., Tarascon J.M., Van Schalkwijk W. 2011. Nanostructured materials for advanced energy conversion and storage devices. Materials for sustainable energy: a collection of peer-reviewed research and review articles from Nature Publishing Group, 148159.

[2] Karaman C., Karaman O., Atar N., Yola M.L. 2021. Tailoring of cobalt phosphide anchored nitrogen and sulfur co-doped three dimensional graphene hybrid: Boosted electrocatalytic performance towards hydrogen evolution reaction. Electrochimica Acta, 380: 138262.

[3] Akça A., Karaman O., Karaman C. 2021. Mechanistic Insights into Catalytic Reduction of $\mathrm{N}_{2} \mathrm{O}$ by $\mathrm{CO}$ over $\mathrm{Cu}$-Embedded Graphene: A Density Functional Theory Perspective. ECS Journal of Solid State Science and Technology, 10 (4): 041003. 
[4] Debe M.K. 2012. Electrocatalyst approaches and challenges for automotive fuel cells. Nature, 486 (7401): 43-51.

[5] Yola M.L., Eren T., Atar N., Saral H., Ermiş İ. 2016. Direct-methanol fuel cell based on functionalized graphene oxide with mono-metallic and bi-metallic nanoparticles: Electrochemical performances of nanomaterials for methanol oxidation. Electroanalysis, 28 (3): 570-579.

[6] Karaman C. Orange Peel Derived-Nitrogen and Sulfur Co-doped Carbon Dots: a Nano-booster for Enhancing ORR Electrocatalytic Performance of 3D Graphene Networks. Electroanalysis, 33: 1356-1369.

[7] Zhang X., Zhu J., Tiwary C.S., Ma Z., Huang H., Zhang J., ... \& Wu Y. 2016. Palladium nanoparticles supported on nitrogen and sulfur dual-doped graphene as highly active electrocatalysts for formic acid and methanol oxidation. ACS applied materials \& interfaces, 8 (17): 10858-10865.

[8] Huang H., Wang X. 2014. Recent progress on carbon-based support materials for electrocatalysts of direct methanol fuel cells. Journal of Materials Chemistry A, 2 (18): 6266-6291.

[9] Qu K., Wu L., Ren J., Qu X. 2012. Natural DNA-modified graphene/Pd nanoparticles as highly active catalyst for formic acid electro-oxidation and for the Suzuki reaction. ACS applied materials \& interfaces, 4 (9): 5001-5009.

[10] Huang Y.X., Xie J.F., Zhang X., Xiong L., Yu H.Q. 2014. Reduced graphene oxide supported palladium nanoparticles via photoassisted citrate reduction for enhanced electrocatalytic activities. ACS applied materials \& interfaces, 6 (18): 15795-15801.

[11] Hu C., Wang X. 2015. Highly dispersed palladium nanoparticles on commercial carbon black with significantly high electro-catalytic activity for methanol and ethanol oxidation. International journal of hydrogen energy, 40 (36): 12382-12391.

[12] Qin Y.H., Jia Y.B., Jiang Y., Niu D.F., Zhang X.S., Zhou X.G., ... \& Yuan W.K. 2012. Controllable synthesis of carbon nanofiber supported Pd catalyst for formic acid electrooxidation. International journal of hydrogen energy, 37 (9): 7373-7377.

[13] Bai Z., Huang R., Niu L., Zhang Q., Yang L., Zhang J. 2015. A facile synthesis of hollow palladium/copper alloy nanocubes supported on N-doped graphene for ethanol electrooxidation catalyst. Catalysts, 5 (2): 747-758.

[14] Lim E.J., Kim Y., Choi S.M., Lee S., Noh Y., Kim W.B. 2015. Binary PdM catalysts (M= Ru, $\mathrm{Sn}$, or Ir) over a reduced graphene oxide support for electro-oxidation of primary alcohols (methanol, ethanol, 1-propanol) under alkaline conditions. Journal of Materials Chemistry A, 3 (10): 5491-5500.

[15] Qu K., Zheng Y., Zhang X., Davey K., Dai S., Qiao S.Z. 2017. Promotion of electrocatalytic hydrogen evolution reaction on nitrogen-doped carbon nanosheets with secondary heteroatoms. ACS nano, 11 (7): 7293-7300.

[16] Ai W., Li J., Du Z., Zou C., Du H., Xu X., ... \& Yu T. 2018. Dual confinement of polysulfides in boron-doped porous carbon sphere/graphene hybrid for advanced Li-S batteries. Nano Research, 11 (9): 4562-4573.

[17] Yang H., Zhang X., Zou H., Yu Z., Li S., Sun J., ... \& Ma J. 2018. Palladium nanoparticles anchored on three-dimensional nitrogen-doped carbon nanotubes as a robust electrocatalyst for ethanol oxidation. ACS Sustainable Chemistry \& Engineering, 6 (6): 7918-7923.

[18] Kakaei K., Rahnavardi M. 2021. Synthesis of nitrogen-doped reduced graphene oxide and its decoration with high efficiency palladium nanoparticles for direct ethanol fuel cell. Renewable Energy, 163: 1277-1286.

[19] Yao C., Zhang Q., Su Y., Xu L., Wang H., Liu J., Hou S. 2019. Palladium nanoparticles encapsulated into hollow $\mathrm{N}$-doped graphene microspheres as electrocatalyst for ethanol oxidation reaction. ACS Applied Nano Materials, 2 (4): 1898-1908. 